\title{
A guanosine 5'-triphosphate-dependent protein kinase is localized in the outer envelope membrane of pea chloroplasts
}

\author{
Jürgen Soll ${ }^{1}$, Irene Fischer ${ }^{1}$, and Kenneth Keegstra ${ }^{2}$ \\ ${ }^{1}$ Botanisches Institut der Universität München, Menzinger Strasse 67, D-8000 München 19, FRG, and \\ 2 Botany Department, University of Wisconsin, Madison, Wisconsin 53706, USA
}

\begin{abstract}
A guanosine 5'-triphosphate (GTP)-dependent protein kinase was detected in preparations of outer chloroplast envelope membranes of pea (Pisum sativum L.) chloroplasts. The proteinkinase activity was capable of phosphorylating several envelope-membrane proteins. The major phosphorylated products were 23- and 32.5-kilodalton proteins of the outer envelope membrane. Several other envelope proteins were labeled to a lesser extent. Following acid hydrolysis of the labeled proteins, most of the label was detected as phosphoserine with only minor amounts detected as phosphothreonine. Several criteria were used to distinguish the GTP-dependent protein kinase from an ATP-dependent kinase also present in the outer envelope membrane. The ATP-dependent kinase phosphorylated a very different set of envelope-membrane proteins. Heparin inhibited the GTP-dependent kinase but had little effect upon the ATP-dependent enzyme. The GTP-dependent enzyme accepted phosvitin as an external protein substrate whereas the ATP-dependent enzyme did not. The outer membrane of the chloroplast envelope also contained a phosphotransferase capable of transferring labeled phosphate from $\left[\gamma_{-}{ }^{32} \mathrm{P}\right] \mathrm{GTP}$ to ADP to yield $\left(\gamma-{ }^{32} \mathrm{P}\right] \mathrm{ATP}$. Consequently, addition of ADP to a GTP-dependent protein-kinase assay resulted in a switch in the pattern of labeled products from that seen with GTP to that typically seen with ATP.
\end{abstract}

Key words: Casein kinase II - Chloroplast envelope - Guanosine triphosphate-ADP phosphotransferase - Guanosine triphosphate-protein kinase - Pisum (protein kinase) - Protein phosphorylation

Abbreviations: GDP (GMP, GTP) $=$ guanosine 5 -diphosphate (mono-, tri-); $\mathrm{kDa}$-kilodalton; $\mathrm{S}_{0.5}=$ concentration of substrate supporting half-maximal velocity; SDS-PAGE = sodium dodecyl sulfate-polyacrylamide gel electrophoresis Tricine $=\mathrm{N}-(2-$ hydroxy-1,1-bis(hydroxymethyl)ethyl)glycine

\section{Introduction}

Protein kinases are widely distributed in eukaryotic cells. The physiological roles of protein kinases have been studied most extensively in animal cells where protein phosphorylation/dephosphorylation cascades play an important role in regulating the activity of many soluble enzymes. In addition, membrane-bound protein kinases play important roles in signal transduction across biological membranes (Edelman et al. 1987).

Numerous protein kinases have been identified in plant cells. Protein kinases of chloroplasts have received considerable attention, with several chloroplast compartments containing protein-kinase activities (Laing and Christeller 1984). Distinct ATP-dependent protein kinases and phosphoproteins are located in the outer envelope membrane (Soll and Buchanan 1983) and in the inner membrane (Soll 1985). The soluble chloroplast-protein fraction was not only demonstrated to have ATPdependent protein-kinase activity (Foyer 1984; Budde and Chollet 1986), but also ADP-dependent protein-kinase activity (Ashton and Hatch 1983). Most extensively studied is the phosphorylation of proteins in the thylakoid membranes by different protein kinases (Allen and Bennett 1981; Lin et al. 1982; Coughlan and Hind 1986; Bhalla and Bennett 1987).

Protein kinases also using GTP as phosphoryldonor are most common enzymes of the casein kinase II type (Hathaway and Traugh 1983). They have been detected in a wide variety of plant and animal tissues (Ventimiglia and Wool 1974; Erdmann et al. 1982; Gowda and Pillay 1982; Yan and Tao 1982; Glover et al. 1983). Protein kinases of this type have not so far been found to depend on any of the well-studied second messengers like cAMP, cGMP, $\mathrm{Ca}^{2+}$ or diacylglycerol. The major exogenous protein substrate for casein kinase II 
are acidic proteins like phosvitin and casein but not histones. Though detailed studies of this protein-kinase class are available even with purified enzymes (for references, see above) no definite physiological role or regulatory function could be ascribed to protein kinases of the casein kinase II type until today.

Despite the reports of protein-kinase activities in plant cells (for a review see Ranjeva and Boudet 1987), knowledge of their roles remains incomplete. For those protein kinases that are found associated with membranes of plant cells, it is tempting to speculate that they are involved in signal transduction at these membranes. For example, a thylakoid protein kinase has been implicated in regulating the distribution of light-harvesting capacity between the two photosystems (Allen and Bennett 1981). Alternatively, it has been suggested that the protein kinases of the chloroplast envelope may have a role in the ATP-dependent transport of cytoplasmically synthesized proteins into chloroplasts (Schindler et al. 1987). During attempts to understand further the role of protein phosphorylation at the chloroplast envelope a GTP-dependent protein kinase was detected. This enzyme was distinct in its biochemical properties and endogenous protein substrates from the ATP-dependent protein kinase described earlier (Soll 1985).

\section{Material and methods}

Plant material. Pea plants (Pisum sativum L., cv. Progress No. 9) were grown in a growth chamber under a 12 -h light-dark regime and $20^{\circ} \mathrm{C}$ constant temperature.

Chemicals. $\left[\gamma^{32} \mathrm{P}\right] \mathrm{GTP}\left(370 \mathrm{GBq} \cdot \mathrm{mmol}^{-1}\right)$ in $50 \%$ ethanol and $\left[\gamma_{-}{ }^{32} \mathrm{P}\right] \mathrm{ATP}\left(110 \mathrm{TBq}-\mathrm{mmol}^{-1}\right)$ were from Amersham (Braunschweig, FRG), Calmodulin antagonist W-5 (N-(6aminohexyl)-1-naphthalene sulfonamide hydrochloride) and protein-kinase inhibitor $\mathrm{H}-9$ (N-(2-aminoethyl)-5-isoquinolinesulfonamide dihydrochloride) were from Seikagaku America Inc., St. Petersburg, Fla., USA. Proteinaeous protein-kinase inhibitor from bovine heart was from Sigma, St. Louis, Mo., USA. Guanosine 5'-triphosphate was used as lithium salt and stored like GDP at $-80^{\circ} \mathrm{C}$. All other chemicals were of reagent grade and used without further purification.

Isolation of chloroplast components. Outer and inner chloroplast envelopes were isolated from 14-d-old pea plants (Fig. 1; Keegstra and Yousif 1986). Chloroplasts were protease-treated with thermolysin at $200 \mu \mathrm{g}$ protease $\cdot \mathrm{mg}^{-1}$ chlorophyll (Joyard et al. 1983; Cline et al. 1984) and separated inner and outer envelope membranes were purified from these plastids (Keegstra and Yousif 1986). Soluble chloroplast proteins were isolated after hypotonic lysis of purified intact chloroplasts and subjected to centrifugation at $50000 \cdot \mathrm{g}$ for $30 \mathrm{~min}$. Thylakoids were isolated after hypotonic lysis and centrifugation of $2000 \cdot \mathrm{g}$ for $2 \mathrm{~min}$ from the same batch of chloroplasts. Thylakoids were washed three times with $10 \mathrm{mmol} \cdot \mathrm{1}^{-1} \mathrm{~N}-[2$-hydroxy-1,1-

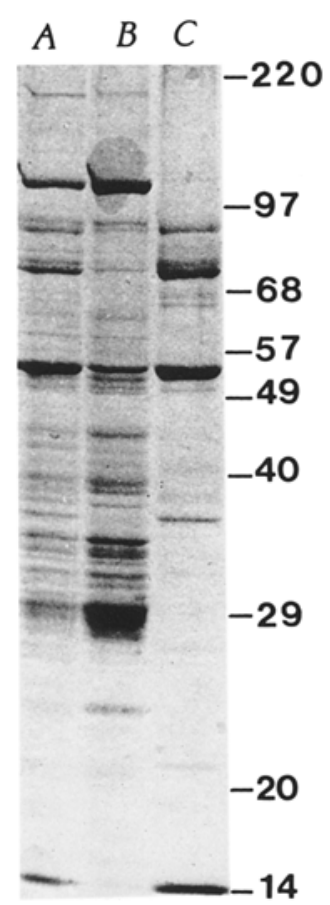

Fig. 1. Purified envelope membranes from pea chloroplasts were analyzed by SDS-PAGE. Lane $A$, mixed envelope membranes; lane $B$, separated inner envelope membranes; lane $C$, purified outer envelope membranes. After SDS-PAGE the gels were stained with Coomassie Brilliant blue. Numbers indicate molecular weights in $\mathrm{kDa}$

bis(hydroxymethyl)ethyl]giycine (Tricine)-KOH pH 7.9 at $100 \mu \mathrm{g}$ chlorophyll $\cdot \mathrm{ml}^{-1}$ (Arnon 1949) and centrifugation of $2000 \cdot g$ for 2 min.

Protein-kinase assay. The ethanol was removed from an aliquot of $\left(\gamma-{ }^{32}\right.$ P]GTP by evaporation under a stream of $\mathrm{N}_{2}$ to less than half the original volume and addition of $\mathrm{H}_{2} \mathrm{O}$ back to the original volume. A protein-kinase assay contained, if not otherwise defined: $8 \mu \mathrm{mol} \cdot 1^{-1} \quad\left[\gamma^{32} \mathrm{P}\right] \mathrm{GTP} \quad(370 \mathrm{GBq}$. mmol ${ }^{-1}$, $5 \mathrm{mmol} \cdot \mathrm{1}^{-1} \mathrm{MgCl}_{2}, 2 \mathrm{mmol} \cdot \mathrm{1}^{-1} \mathrm{MnCl}_{2}, 25 \mathrm{mmol}$. $1^{-1}$ Tricine-KOH pH 7.9 and about $2.5 \mu \mathrm{g}$ envelope-membrane proteins in a final volume of $25 \mu$ l. Reactions were initiated by the addition of membranes and carried out at $20^{\circ} \mathrm{C}$ for 5-15 min. Assays with ATP kinase were done under the conditions described in Soll (1985). The incubation was terminated by the addition of 1 vol. of twofold-concentrated solubilization buffer (Laemmli 1970).

Analysis of the phosphorylation reaction. Samples were analyzed by sodium dodecyl sulfate-polyacrylamide gel electrophoresis (SDS-PAGE; Laemmli 1970) using a 10\% running gel. Gels were stained with Coomassie Brilliant blue and destained in the presence of $20 \mathrm{mmol} \cdot 1^{-1} \mathrm{KH}_{2} \mathrm{PO}_{4}$. Dried gels were exposed to film overnight (Kodak X-AR 5) at $-80^{\circ} \mathrm{C}$, using an intensifying screen. Bands of ${ }^{32} \mathrm{P}$-phosphoprotein were subsequently localized on the gel, cut out, rehydrated with $500 \mu 1 \mathrm{H}_{2} \mathrm{O}$ and the radioactivity quantitated by liquid scintillation counting.

Phosphoamino-acid analysis. The protein-kinase assay was stopped by the addition of 10 vol. of $10 \%$ trichloracetic acid $(\mathrm{w} / \mathrm{v})$ and washed three times with $5 \%$ trichloracetic acid prior 
to hydrolysis at $110^{\circ} \mathrm{C}$ for $1-2 \mathrm{~h}$ in $6 \mathrm{~N} \mathrm{HCl}$. Twenty $\mu \mathrm{g}$ of the unlabeled phosphoamino-acids P-tyrosine P-threonine and $\mathrm{P}$-serine were added to the reaction. The mixture was dried under a stream of $\mathrm{N}_{2}$, dissolved in $20 \mu 1 \mathrm{H}_{2} \mathrm{O}$ and spotted onto a precoated Silica-gel thin-layer chromatography plate (Merck, Darmstadt, FRG; Kieselgel 60) and subjected to electrophoresis under water cooling for $4 \mathrm{~h}$ at $1000 \mathrm{~V}$ using acetic acid: formic acid: $\mathrm{H}_{2} \mathrm{O}(78: 25: 897$; by vol.) as developing solvent. The position of phosphoamino acids was located by ninhydrin staining and radioactivity was localized and detected by autoradiography.

\section{Results}

During efforts to characterize the protein-kinase activity present in preparations of outer envelope membranes derived from pea chloroplasts (Soll 1985), the nucleotide specifity of the kinase was examined. In these studies, it was observed that $\left[\gamma-{ }^{32} \mathrm{P}\right]$ GTP could serve as phosphoryl donor, but the pattern of labeled proteins was appreciably different from that observed when $\left[\gamma^{32} \mathrm{P}\right] \mathrm{ATP}$ was used (Fig. 2, lanes 11-12). In order to gain a more complete picture of the presence of GTP-dependent protein-kinase activities in chloroplasts, the protein-kinase activities of all chloroplast fractions were measured, using both $\left[\gamma-{ }^{32} \mathrm{P}\right] \mathrm{ATP}$ and $[\gamma-$ $\left.{ }^{32} \mathrm{P}\right] \mathrm{GTP}$. The results of these analyses are shown in Fig. 2, lanes $1-10$. The extent of ${ }^{32} \mathrm{P}$ incorporation varied to some degree from preparation to preparation for proteins which were not the major phosphorylation products. The results of SDSPAGE of purified envelope membranes are shown in Fig. 1 and demonstrate the purity of the respective membrane population and the typical distribution of envelope marker proteins (Cline et al. 1984). As can be seen in lanes $1-5$, when $[\gamma-$ $\left.{ }^{32} \mathrm{P}\right] \mathrm{ATP}$ is used as the phosphoryl donor, each of the chloroplast fractions yields a distinctive pattern of labeled polypeptides. On the other hand, when $\left[\gamma-{ }^{32} \mathrm{P}\right] \mathrm{GTP}$ is used, only preparations of the thylakoid membrane and the outer envelope membrane show appreciable labeling. The labeling patterns observed with $\left[\gamma^{32} \mathrm{P}\right]$ ATP and $\left[\gamma-{ }^{32} \mathrm{P}\right] \mathrm{GTP}$ labeling of thylakoids (Fig. 2, lanes 1 and 10, respectively) look similar and most likely result from the action of the same protein kinase. However, the patterns observed following $\left[\gamma^{32}\right]$ ATP and $[\gamma-$ $\left.{ }^{32} \mathrm{P}\right] \mathrm{GTP}$ labeling of outer envelope membranes are distinctly different from each other (Fig. 2, lanes 11 and 12). The simplest interpretation is that these different patterns result from the action of two separate protein kinases, one specific for ATP and one specific for GTP. In an effort to evaluate this hypothesis, both the ATP-dependent and GTP-dependent activities were subjected to further characterization.
The two protein-kinase activities of the outer envelope membrane display dramatically different sensitivities to inhibition by heparin (Hathaway et al. 1980). As shown in Fig. 3, the phosphorylation of envelope-membrane proteins by $[\gamma$ $\left.{ }^{32} \mathrm{P}\right]$ GTP is severely inhibited by heparin. The labeling of the $23-\mathrm{kDa}$ protein is inhibited $50 \%$ by $0.15 \mathrm{mU} \cdot \mathrm{ml}^{-1}\left(0.88 \mathrm{ng} \cdot \mathrm{ml}^{-1}\right)$ heparin and the labeling of the $32.5-\mathrm{kDa}$ protein is inhibited $50 \%$ by $0.2 \mathrm{mU} \cdot \mathrm{ml}^{-1}\left(1.2 \mathrm{ng} \cdot \mathrm{ml}^{-1}\right)$ heparin. On the other hand, inhibition of labeling with $\left[\gamma^{32}\right.$ P]ATP is variable. Several proteins show no decrease in labeling at the highest level of heparin examined. However, the 23- and 32.5-kilodalton $(\mathrm{kDa})$ proteins show inhibition of labeling similar to that observed with $\left[\gamma^{32} \mathrm{P}\right] \mathrm{GTP}$. These observations support the conclusion that there are two different protein kinases in the outer envelope membrane.

Further evidence for the presence of two enzymes comes from analysis of the inhibitory effects of nucleoside diphosphates. It was demonstrated previously that ADP acts as an inhibitor of the ATP-dependent kinase (Soll 1985). The data in Fig. 4 demonstrate that GDP serves as an inhibitor of the GTP-dependent kinase. Efforts to examine the effects of ADP on the GTP-dependent protein kinase led to unexpected results. Rather than cause an inhibition of the GTP-dependent protein kinase, addition of ADP caused a switch in the pattern of phosphorylated products (Fig. 5). Addition of $10 \mu \mathrm{mol} \cdot 1^{-1}$ ADP to a labeling reaction using $\left[\gamma^{32} \mathrm{P}\right]$ GTP resulted in a shift in the pattern of labeled polypeptides to that observed when labeling was conducted with $\left[\gamma-{ }^{32} \mathrm{P}\right]$ ATP (compare lanes 1, 2 and 3 in Fig. 5). Addition of $100 \mu \mathrm{mol}$. $1^{-1} \mathrm{ADP}$ also resulted in the ATP labeling pattern, but also caused a reduction in the amount of labeling, presumably because of the inhibitory effect of ADP (Fig. 5, lane 4; Soll 1985). Addition of $10 \mu \mathrm{mol} \cdot 1^{-1}$ or $100 \mu \mathrm{mol} \cdot 1^{-1}$ GDP caused the expected inhibition of labeling (Fig. 5, lanes 5 and 6).

This unexpected result of ADP addition could be explained if the preparation from the outer envelope membrane also contained a nucleotidephosphotransferase activity that could transfer a phosphate from GTP to ADP to yield ATP and GDP. Assays were conducted to measure for such an activity in an effort to provide direct evidence to support this explanation. As shown in Fig. 6, outer envelope membranes do contain an activity which converts $\left[\gamma^{32} \mathrm{P}\right] \mathrm{GTP}$ to radioactive ATP when ADP is present.

To provide evidence that the switch in the phosphorylation pattern was caused by the action of 
$\begin{array}{llllllllll}1 & 2 & 3 & 4 & 5 & 6 & 7 & 8 & 9 & 10\end{array}$

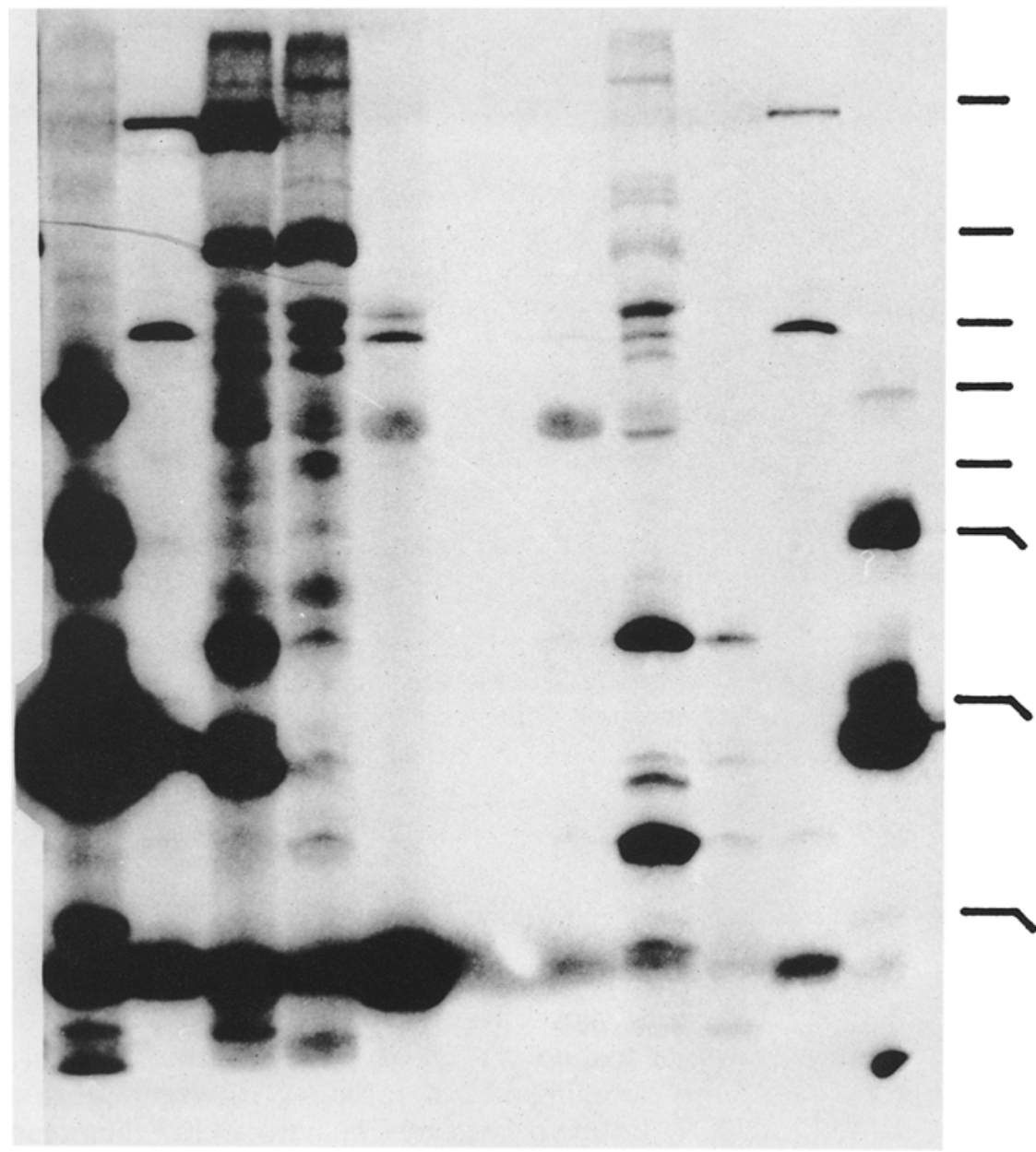

220

97

68

57

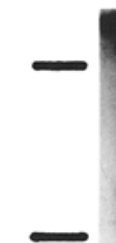

$11 \quad 12$

Fig. 2. Protein phosphorylation in pea chloroplast compartments using $\left[\gamma-{ }^{32} \mathrm{P}\right] \mathrm{ATP}$ and $\left[\gamma_{-}{ }^{32} \mathrm{P}\right] \mathrm{GTP}$. Left panel, lanes $1-5$ show protein-phosphorylation patterns of thylakoids (1), chloroplast-soluble proteins (2), inner envelope (3), outer envelope (4) and thermolysin-treated outer envelope (5) using $\left[\gamma^{32} \mathrm{P}\right]$ ATP. Lanes $6-10$ show protein-phosphorylation pattern of thermolysin-treated outer envelope (6), outer envelope (7), inner envelope (8), chloroplast-soluble proteins ( 9$)$ and thylakoids $(10)$ using $\left[\gamma-{ }^{32} \mathrm{P}\right] \mathrm{GTP}$. Equal amounts of proteins were incubated with $\left[\gamma^{32} \mathrm{P}\right] \mathrm{ATP}$ and $\left[\gamma^{32} \mathrm{P}\right] \mathrm{GTP}\left(8 \mu \mathrm{mol} \cdot 1^{-1}\right)$ of the same specific activity $(370 \mathrm{GBq}$. $\mathrm{mmol}^{-1}$ ) for 5 min and further analyzed by SDS-PAGE as described in Material and methods. The right panel shows a more direct comparison of protein phosphorylation in the outer chloroplast envelope using $\left[\gamma_{-}{ }^{32} \mathrm{P}\right] \mathrm{GTP}($ lane 11$)$ and $\left[\gamma-{ }^{32} \mathrm{P}\right] \mathrm{ATP}$ (lane 12). All other conditions were as described above. Numbers between panel A and B indicate molecular weights in $\mathrm{kDa}$. Both panels show autoradiographs

the nucleotide phosphotransferase and not be the action of adenylate kinase (Murakami and Strotmann 1978; Birkenhead et al. 1982), labeling was performed in the presence of P1, P5-di(adenosine$5^{\prime}$ )pentaphosphate, a known inhibitor of adenylate kinase (Lienhard and Secemski 1973). When the experiment shown in lanes 1,3 and 4 of Fig. 5 was repeated in the presence of P1, P5-di(adenosine-5') pentaphosphate (from 4 to $60 \mu \mathrm{mol} \cdot \mathrm{I}^{-1}$ ) the switch in patterns shown in Fig. 5 still occurred (data not shown). Thus we tentatively conclude that the change in labeling pattern is not due to the action of adenylate kinase and is most likely due to the action of the nucleotide phosphotransferase. Further support for this conclusion will require a more detailed characterization of the nucleotide-phosphotransferase activity.

These results indicate the presence of two distinct protein-kinase activities in the outer chloroplast envelope. Further discrimination between the two kinases was made possible by their specificity with externally added protein substrates. Phosvitin 

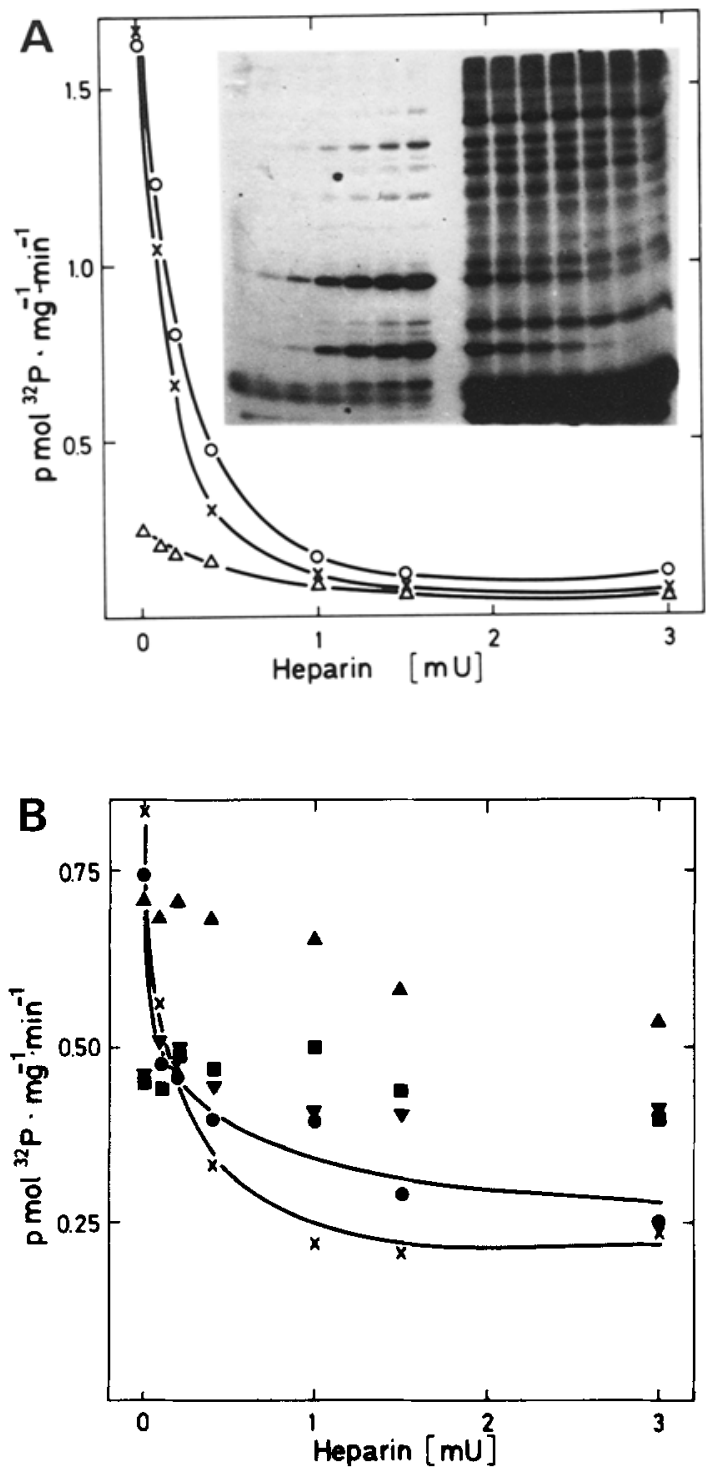

Fig. 3A, B. Inhibition by heparin $\left(\mathrm{mU} \cdot \mathrm{ml}^{-1}\right)$ of outer-envelope-bound GTP and ATP protein kinases from pea chloroplasts. Discrimination between the ATP and GTP kinase was made possible by their different responses to heparin. A The response to heparin in the presence of $\left[\gamma_{-}{ }^{32} \mathrm{P}\right] \mathrm{GTTP} ; 23-(x-x)$, $32.5-(\circ-0)$, and $74-\mathrm{kDa}(\Delta-\Delta)$ proteins. $B$ The inhibition of protein phosphorylation by heparin in the presence of $[\gamma$ ${ }^{32}$ P]ATP; 23- $(\times), 32.5-(\bullet), 58-(\boldsymbol{\bullet}), 74-(\boldsymbol{\nabla})$, and 86-kDa («) proteins. The insert in $\mathbf{A}$ shows the autoradiogram of the data quantitated in $\mathbf{A}$ and $\mathbf{B}$. Heparin inhibition is demonstrated for GTP (left) and ATP (right). Heparin concentrations increase from the center to the outsides

$\left(1 \mathrm{mg} \cdot \mathrm{ml}^{-1}\right)$ an acidic protein is accepted as external protein substrate using $\left[\gamma-{ }^{32} \mathrm{P}\right] \mathrm{GTP}$ (data not shown). Both the membrane-bound (Soll 1985) and also the purified ATP-dependent kinase do not use this acidic protein as phosphate acceptor, but uses Histone IIIs as preferred acceptor protein

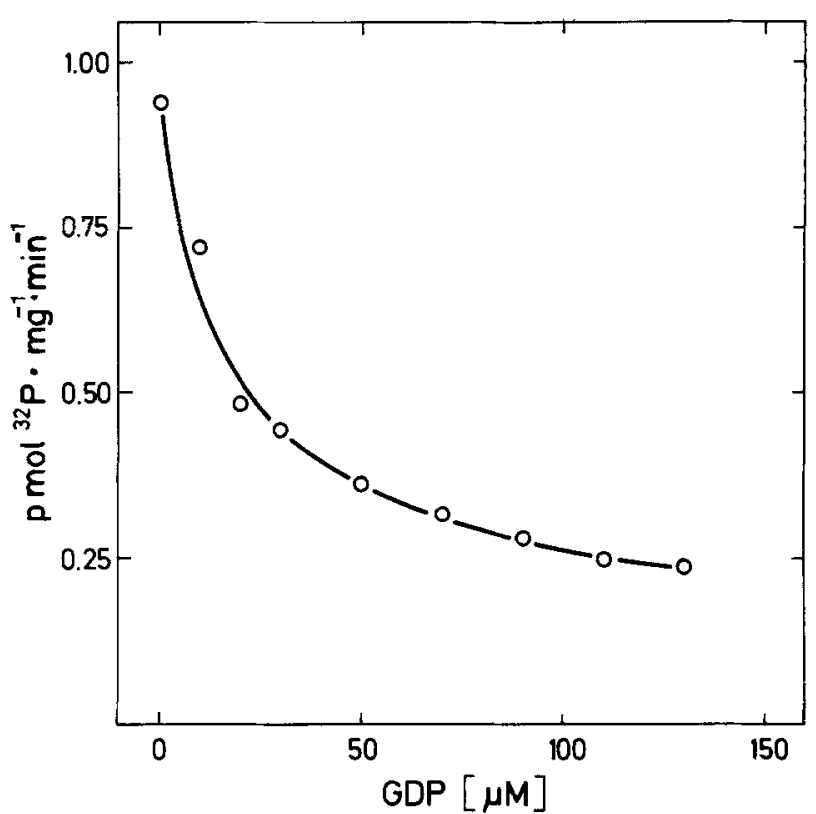

Fig. 4. Inhibition of GTP-dependent protein phosphorylation by GDP in outer envelope membranes of pea chloroplasts. Phosphorylation products were analysed by SDS-PAGE and incorporation rates were quantified by liquid scintillation counting as described above. Incorporation rates were calculated as the sum of ${ }^{32} \mathrm{P}$-label in the 23-plus $32.5-\mathrm{kDa}$ proteins

(Soll 1988). Phosphorylation of envelope proteins by GTP shows a temperature optimum of $20^{\circ} \mathrm{C}$ while phosphorylation in the presence of ATP exhibits a temperature optimum between 30 and $37^{\circ} \mathrm{C}$. Both enzymes are still active at low temperature and have residual activities of about $30 \%$ and $15 \%$ at 0 and $-12^{\circ} \mathrm{C}$, respectively (assay in presence of $25 \%$ glycerol; data not shown).

Radiolabelled phosphorus from $\left[\gamma^{32} \mathrm{P}\right] \mathrm{GTP}$ was incorporated into membrane proteins in a time- and protein-concentration-dependent manner. Incorporation rates were linear up to $15 \mathrm{~min}$ and up to a final membrane protein concentration of $1 \mathrm{mg} \cdot \mathrm{ml}^{-1}$ (data not shown). We therefore chose a time between 5 and $15 \mathrm{~min}$ and a protein concentration of $0.1 \mathrm{mg} \cdot \mathrm{ml}^{-1}$ for our standard incubation. The outer-envelope-bound GTP kinase has a high affinity for its substrate GTP, and an $\mathrm{S}_{0.5}$ (concentration of substrate supporting halfmaximal velocity) of $1.5 \mu \mathrm{mol} \cdot 1^{-1}$ was determined from (Fig. 7). Maximal incorporation rates were about $1-5 \mathrm{pmol} \cdot(\mathrm{mg} \text { protein })^{-1} \cdot \mathrm{min}^{-1}$. The GTP kinase had a broad $\mathrm{pH}$ optimum between $\mathrm{pH} 7$ and 8 with steep decreases in activity at more acidic or alkaline pHs (Fig. 7, insert). Analysis of the phosphorylated amino acids showed that most $(90 \%)$ of the label was present in phosphoserine 


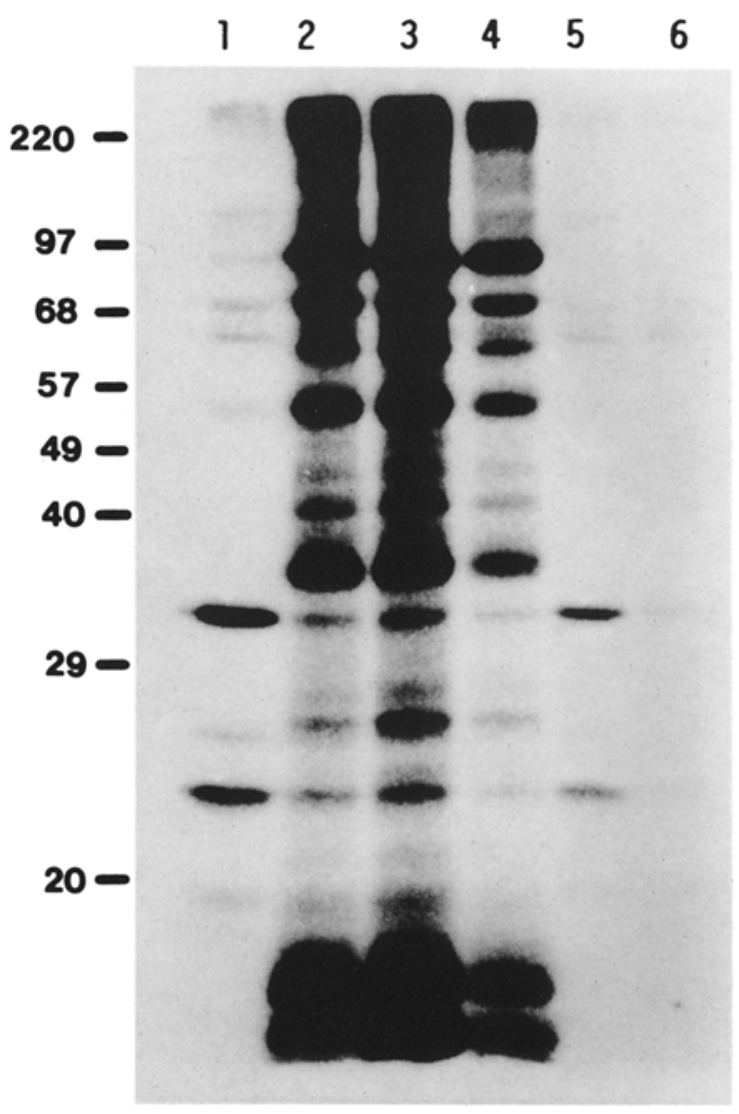

Fig. 5. Effect of ADP on the $\left[\gamma^{32} \mathrm{P}\right] \mathrm{GTP}$-dependent phosphorylation of polypeptides in the outer envelope membranes of pea chloroplasts. Lane 1, phosphorylation by $\left[\gamma^{32} \mathrm{P}\right] \mathrm{GTP}(16 \mu \mathrm{mol}$. $\left.1^{-1}, 185 \mathrm{GBq} \cdot \mathrm{mmol}^{-1}\right)$, lane 2 , phosphorylation by $[\gamma$ ${ }^{32}$ P]ATP $\left(16 \mu \mathrm{mol} \cdot 1^{-1}, 185 \mathrm{GBq} \cdot \mathrm{mmol}^{-1}\right) ;$ lane $3,[\gamma-$ $\left.{ }^{32} \mathrm{P}\right] \mathrm{GTP}+10 \mu \mathrm{mol} \cdot 1^{-1}$ ADP; lane $4,\left[\gamma_{-}{ }^{32} \mathrm{P}\right] \mathrm{GTP}+100 \mu \mathrm{mol}$. $1^{-1}$ ADP; lane 5, $\left[\gamma^{-32} \mathrm{P}\right] \mathrm{GTP}+10 \mu \mathrm{mol} \cdot 1^{-1} \mathrm{GDP}$; lane $6,[\gamma-$ $\left.{ }^{32} \mathrm{P}\right] \mathrm{GTP}+100 \mu \mathrm{mol} \cdot \mathrm{1}^{-1}$ GDP. Samples were analyzed on a $12^{1} 12 \%$ running gel; all other conditions were as described in Material and methods

while little $(10 \%)$ was detected in phosphothreonine (data not shown).

Many protein kinases depend on the presence of divalent cations for maximal activity. In our hands, the GTP-dependent kinase required both $\mathrm{Mg}^{2+}$ and $\mathrm{Mn}^{2+}$ for maximal activity. No incorporation was detected in the absence of divalent cations (Fig. 8). Maximal activity was observed at $10 \mathrm{mmol} \cdot 1^{-1} \mathrm{Mg}^{2+}$ and $2 \mathrm{mmol} \cdot 1^{-1} \mathrm{Mn}^{2+}$. Increasing the $\mathrm{Mg}^{2+}$ concentration up to $15 \mathrm{mmol}$. $\mathrm{1}^{-1}$ in the absence of $\mathrm{Mn}^{2+}$ resulted in a continual increase in enzyme activity with both endogenous membrane protein substrates (Fig. 8). Increasing the $\mathrm{Mn}^{2+}$ concentration produced different responses for the phosphorylation of the 23- and

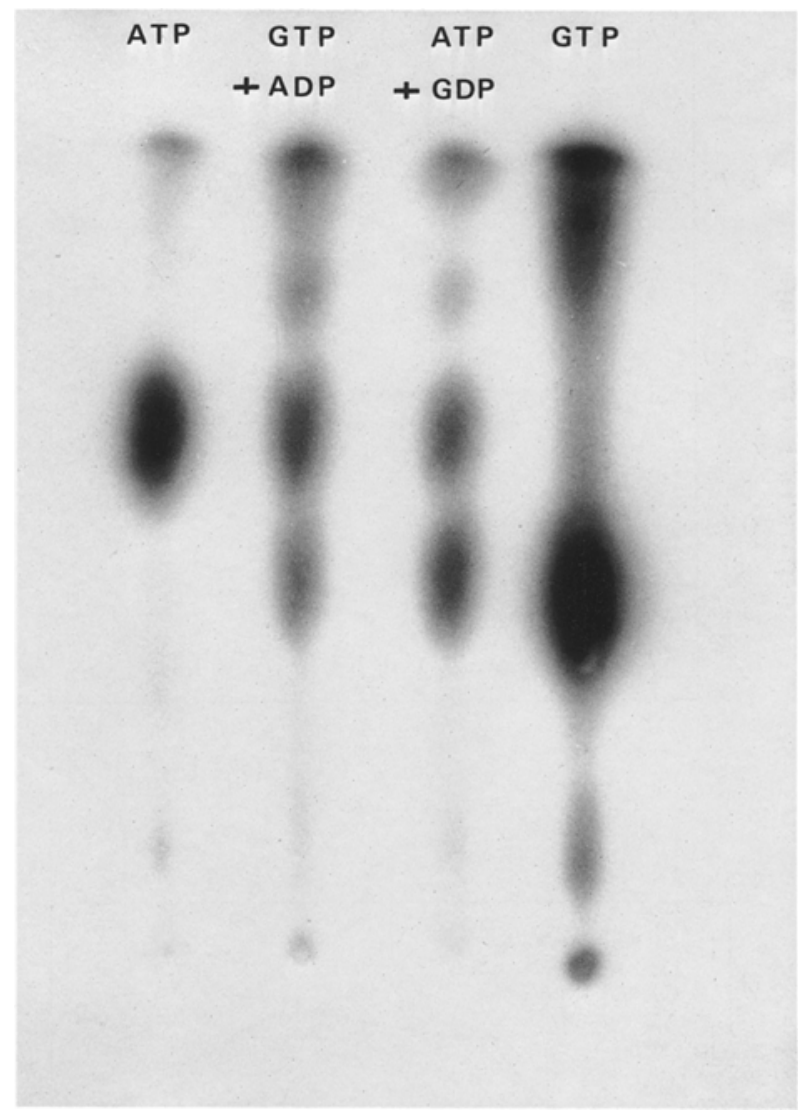

Fig. 6. Detection of a nucleotide triphosphate-nucleotide diphosphate phosphotransferase in the outer-envelope membrane fraction of pea chloroplasts. The presence of a phosphotransferase activity was evaluated directly using thin-layer-chromatography analysis of the reaction products. A phosphotransferase reaction was conducted in $20 \mathrm{mmol} \cdot \mathrm{1}^{-1}$ Tricine- $\mathrm{KOH} \mathrm{pH} 7.9$, $4 \mathrm{mmol} \cdot 1^{-1} \mathrm{MgCl}_{2}, 60 \mu \mathrm{mol} \cdot 1^{-1}\left[\gamma^{-32} \mathrm{P}\right] \mathrm{NTP}, 60 \mu \mathrm{mol} \cdot 1^{-1}$ $\mathrm{NDP}, 10 \mu \mathrm{g}$ protein, for $10 \mathrm{~min}$ at $20^{\circ} \mathrm{C}$ in a final volume of $25 \mu \mathrm{l}$. A $1-\mu \mathrm{l}$ aliquot was spotted onto precoated polyethylene imine cellulose plates (G 1440 PEI; Schleicher \& Schüll, Dassel, FRG) and developed in $1 \mathrm{~mol} \cdot 1^{-1} \mathrm{KH}_{2} \mathrm{PO}_{4}$. Authentic $[\gamma-$ $\left.{ }^{32} \mathrm{P}\right] \mathrm{ATP}$ and $\left[\gamma^{32} \mathrm{P}\right] \mathrm{GTP}$ were run as internal standards

32.5-kDa proteins (Fig. 8): ${ }^{32} \mathrm{P}-\mathrm{label}$ in the $23-\mathrm{kDa}$ protein increased up to $15 \mathrm{mmol} \cdot 1^{-1} \mathrm{Mn}^{2+}$ while maximal incorporation into the $32.5-\mathrm{kDa}$ protein was obtained at $2 \mathrm{mmol} \cdot 1^{-1} \mathrm{Mn}^{2+}$; higher $\mathrm{Mn}^{2+}$ concentration resulted in an inhibition. The inhibition was overcome by the simultaneous inclusion of $\mathrm{Mg}^{2+}$ (Fig. 8). The presence of $\mathrm{Ca}^{2+}$ (5$\left.500 \mu \mathrm{mol} \cdot 1^{-1}\right)$ or $\mathrm{Ca}^{2+}$ plus calmodulin (10 U, $0.3 \mu \mathrm{g}$ ) had no effect upon enzyme activity. Assays were done in the presence of $1 \mathrm{mmol} \cdot 1^{-1}$ ethylene diaminetetraacetic acid (EDTA); the $\mathrm{Ca}^{2+}$ concentrations used above represent the unchelated amount of $\mathrm{Ca}^{2+}$ in the assay. Furthermore the calmodulin antagonist $\mathrm{W}-5$, which causes $50 \%$ inhibition of calmodulin-dependent kinases when pres- 


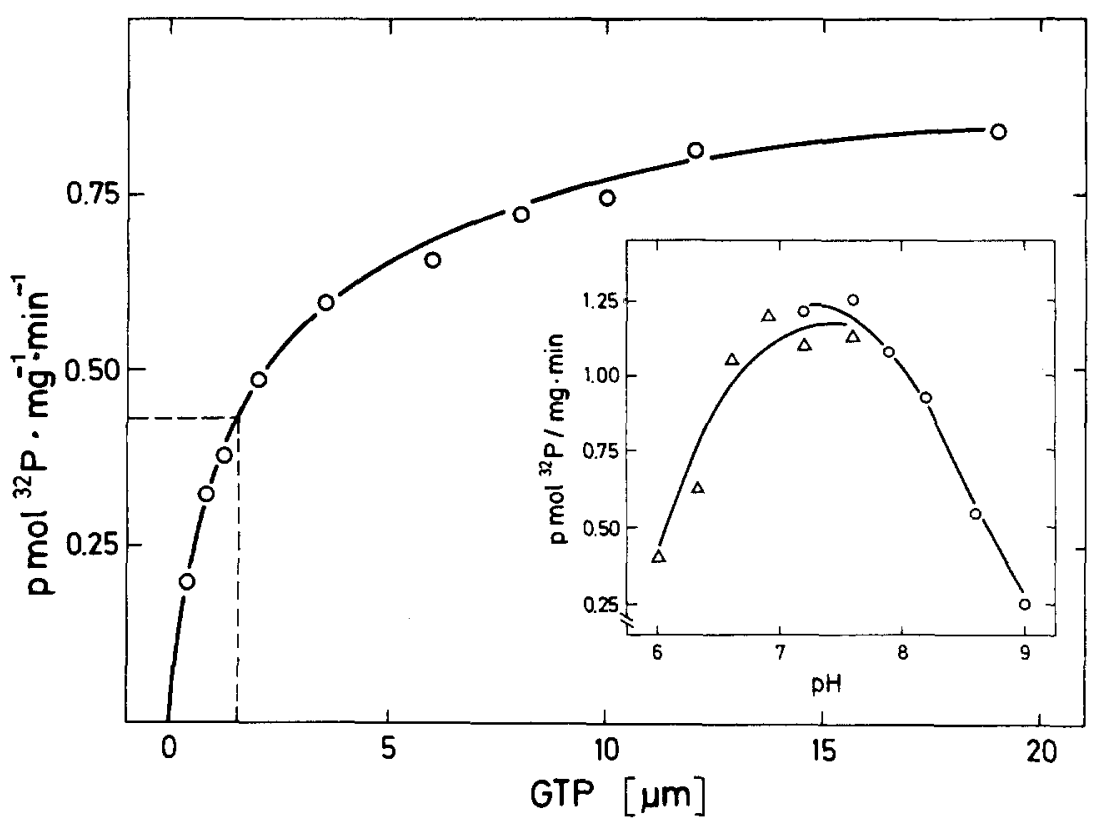

Fig. 7. Influence of GTP concentration upon the activity of GTP-dependent protein kinase from outer envelope membranes of pea chloroplasts. Incorporation rates were calculated as the sum of ${ }^{32} \mathrm{P}$ label in the 23 plus 32.5 $\mathrm{kDa}$ proteins, which were excised from the gel and quantitated as described in Material and methods. Both proteins show the same response to increasing substrate concentrations. Insert $\mathrm{pH}$-Dependence of ${ }^{32} \mathrm{P}$ incorporation into outer-envelope polypeptides from $\left[\gamma^{32} \mathrm{P}\right] \mathrm{GTP}$. The buffer used in the acidic range was $50 \mathrm{mmol} \cdot 1^{-1}$ [bis(2hydroxyethyl)iminotris(hydroxymethyl)methane]-HCl $(\triangle-\triangle)$ whereas $50 \mathrm{mmol} \cdot 1^{-1}$ Tricine$\mathrm{KOH}(\mathrm{O}-\mathrm{O})$ was used in the alkaline range

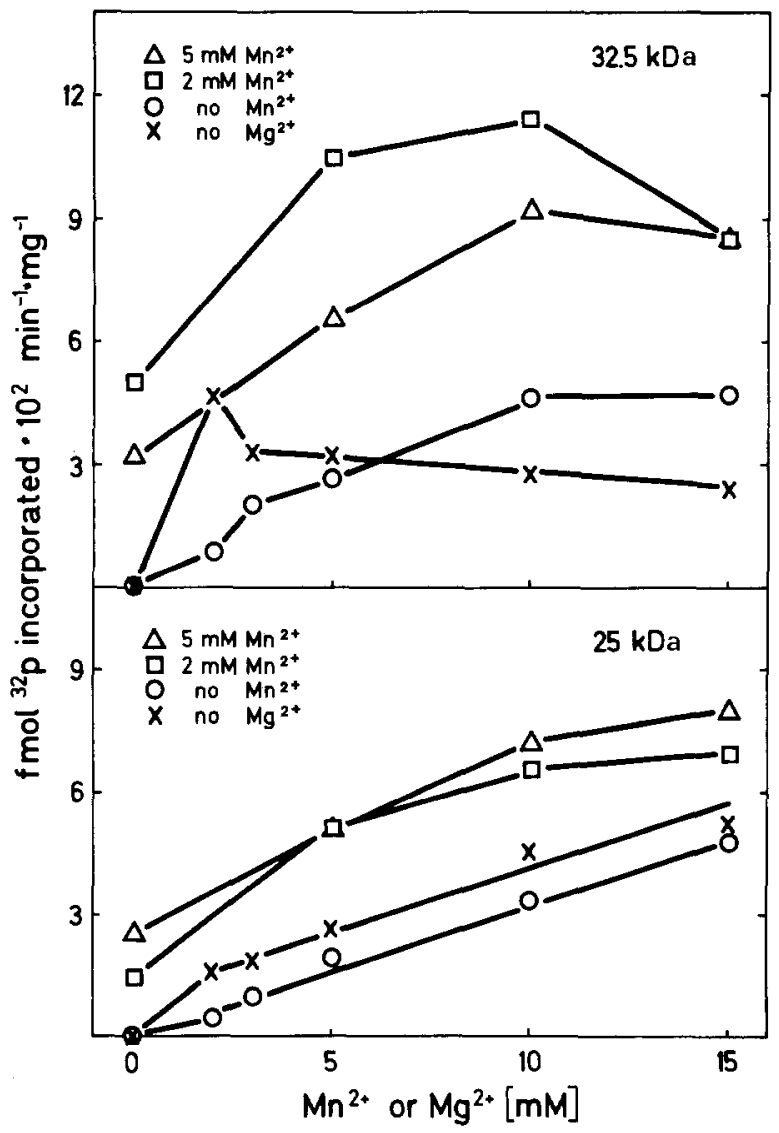

Fig. 8. Effect of divalent cations on the GTP-dependent phosphorylation of polypeptides from the outer envelope membranes of pea chloroplasts. Enzyme activity was measured by keeping either the $\mathrm{Mn}^{2+}$ or $\mathrm{Mg}^{2+}$ concentration constant while the other was varied. The upper part of the figure shows the results obtained for the $32.5-\mathrm{kDa}$ protein, the lower part shows the results for the $23-\mathrm{kDa}$ polypeptide ent at $250 \mu \mathrm{mol} \cdot 1^{-1}$ (Chafouleas et al. 1982), had no effect on the GTP-dependent kinase at $2 \mathrm{mmol}$. $1^{-1}$ final concentration.

No effect on the GTP-dependent kinase was observed with GMP $\left(0-0.4 \mathrm{mmol} \cdot \mathrm{1}^{-1}\right)$, cGMP $(0$ $\left.0.1 \mathrm{mmol} \cdot \mathrm{l}^{-1}\right)$ or the protein kinase inhibitor $\mathrm{H}-9$ $\left(0-20 \mu \mathrm{mol} \cdot 1^{-1}\right)$. The drug $\mathrm{H}-9$ has been shown to inhibit cGMP dependent protein kinase $(\mathrm{Ki}$ $0.87 \mu \mathrm{mol} \cdot \mathrm{1}^{-1}$; Hidaka et al. 1984). The proteineaous protein kinase inhibitor (Edelmann et al. 1987) caused less than $50 \%$ inhibition at a final concentration of $40 \mu \mathrm{g}$ inhibitor per $\mathrm{ml}$.

\section{Discussion}

The present study provides evidence for the existence of a GTP-dependent protein kinase of the casein kinase II type (Hathaway and Traugh 1979, 1983; Edelman et al. 1987) in the outer envelope membrane from pea chloroplasts. The reasoning for this classification is the following: (i) the protein-kinase activity is independent of cGMP, cAMP, $\mathrm{Ca}^{2+}$ or calmodulin; (ii) the $\mathrm{S}_{0.5}$ for GTP is very low $\left(1.5 \mu \mathrm{mol} \cdot 1^{-1}\right.$ while for casein kinase I the $\mathrm{K}_{\mathrm{m}}$ for GTP is generally high $\left(1 \mathrm{mmol} \cdot 1^{-1}\right)$, and for other casein type II enzymes the $S_{0.5}$ for GTP is about 10-20-fold higher than that reported here (Hathaway and Traugh 1983; Edelman et al. 1987); (iii) the protein kinase accepts phosvitin as an acidic external protein substrate in the presence of $\left[\gamma-{ }^{32} \mathrm{P}\right] \mathrm{GTP}$; (iiii) the GTP-dependent protein kinase is strongly inhibited by heparin (Table 1 ; Hathaway et al. 1980). Protein kinases of this type 
Table 1. Comparison of outer-envelope-bound protein-kinase activities using $\left[\gamma-{ }^{32} \mathrm{P}\right] \mathrm{GTP}$ and $\left[\gamma-{ }^{32} \mathrm{P}\right] \mathrm{ATP}$

\begin{tabular}{|c|c|c|}
\hline $\begin{array}{l}\text { Protein phosphorylation } \\
\text { in the presence of: }\end{array}$ & GTP & ATP \\
\hline Sensitive to heparin & yes & no \\
\hline Phosvitin as exogenous substrate & yes & no \\
\hline Temperature optimum & $20^{\circ} \mathrm{C}$ & $30-37^{\circ} \mathrm{C}$ \\
\hline $\begin{array}{l}\mathrm{S}_{0.5} \text { of the } \\
\text { membrane-bound enzyme }\end{array}$ & $1.5 \mu \mathrm{M} \mathrm{GTP}$ & $37 \mu \mathrm{M}$ АTP \\
\hline Preferentially labeled proteins & $\begin{array}{l}32.5 \mathrm{kDa} \\
23 \mathrm{kDa}\end{array}$ & $\begin{array}{l}86 \mathrm{kDa} \\
18 \mathrm{kDa}\end{array}$ \\
\hline $\begin{array}{l}\text { Highly dependent } \\
\text { on divalent cations }\end{array}$ & yes & no \\
\hline
\end{tabular}

have been described from wheat germ (Yan and Tao 1982), isolated nuclei of tobacco (Erdmann et al. 1982) and soybean cotyledons (Gowda and Pillay 1982). In most cases the subcellular localization was not determined. The outer envelope of pea chloroplasts contains at least two protein-kinase activities, an ATP-dependent protein kinase (Soll and Buchanan 1983; Soll 1985) and the GTPdependent kinase described above.

Several criteria were used as evidence that the two activities are not a result of the same enzyme. First the GTP-dependent enzyme phosphorylates a different set of endogenous membrane proteins (Fig. 2). Second, the two enzymes differ in their response to heparin. The GTP-dependent protein kinase is inhibited by heparin whereas the ATPdependent activity generally is not. The GTP-dependent protein kinase may also use $\left[\gamma-{ }^{32} \mathrm{P}\right] \mathrm{ATP}$ as a substrate. This tentative conclusion is derived from the observation that heparin exerts an inhibitory effect on ATP-dependent phosphorylation of only the $23-\mathrm{kDa}$ and the $32.5-\mathrm{kDa}$ polypeptides, whereas the phosphorylation of other outer envelope proteins is not affected (Fig. 3). Third, the two activities differ in a number of biochemical parameters. For example, their response to divalent metal ions is quite different. The GTP-dependent enzyme absolutely requires $\mathrm{Mn}^{2+}$ or $\mathrm{Mg}^{2+}$, whereas the outer-envelope-bound ATP-dependent protein kinase is not completely dependent on divalent cations and shows only $50 \%$ stimulation in the presence of $2 \mathrm{mmol} \cdot 1^{-1} \mathrm{Mg}^{2+}$ (Soll 1985).

Interestingly, the simultaneous inclusion of ADP and $\left[\gamma_{-}^{32} \mathrm{P}\right]$ GTP in the phosphorylation assay gave rise to a typical $\left[\gamma_{-}{ }^{32} \mathrm{P}\right]$ ATP phosphorylation pattern, indicating that a very active nucleotide phosphotransferase is present in the membrane fraction used. Further evidence for this was provided by an assay which directly measures this enzyme. Preliminary observations indicate that the addition of unlabeled ATP to the phosphorylation mixture including radioactive $\left[\gamma^{32} \mathrm{P}\right] \mathrm{GTP}$ results in a shift of the labeling pattern similar to that observed with unlabeled ADP (data not shown). Similar phosphotransferase activities were reported to exist in crude extracts of swine heart and several rat tissues (Kuo 1974).

The chloroplasts are strictly compartmentalized organelles, having three separate membrane systems (outer envelope, inner envelope and thylakoids) and three separate soluble spaces (envelope lumen, stroma and thylakoid lumen). Today, data are available for protein-phosphorylation activities in all of these compartments except the thylakoid lumen (Ranjeva and Boudet 1987; Soll and Bennett 1988).

As can be seen from Fig. 2, thylakoid polypeptides and in particular the light-harvesting complex protein show the highest total ${ }^{32} \mathrm{P}$-incorporation rates. However, envelope membranes show strong incorporation rates in comparison with stroma proteins and a larger number of labeled proteins in comparison with stroma and thylakoids. Assuming that the envelope-membrane proteins account for about $1 \%$ of total chloroplast proteins (Douce et al. 1984), the overall ${ }^{32} \mathrm{P}$-incorporation into envelope proteins is low compared with thylakoid protein phosphorylation but probably accounts for more than $5 \%$ of the total label present in all chloroplast phosphoproteins. In-organello labeling, using intact pea chloroplasts and $\left[\gamma-{ }^{32} \mathrm{P}\right] \mathrm{ATP}$ in the dark ( $30 \mathrm{nmol} \cdot 1^{-1}$ at $4^{\circ} \mathrm{C}$ for $60 \mathrm{~s}$ ), showed that under these conditions about $90 \%$ of the radioactive label was present in envelope-membrane polypeptides (Soll and Bennett 1988). The exposed localization of the envelope-membrane compartment as a barrier between the organelle and the cell as well as its multiple enzymatic functions make it most likely that phosphorylation at this membrane is a major regulatory phenomenon.

This work was supported by grants from the Deutsche Forschungsgemeinschaft and from the U.S. National Science Foundation.

\section{References}

Allen, J.F., Bennett, J. (1981) Photosynthetic protein phosphorylation in intact chloroplasts. FEBS Lett. 123, 247-253

Arnon, D.J. (1949) Copper enzymes in isolated chloroplasts. Polyphenoloxidase in Beta wulgaris. Plant Physiol. 24, 1-15

Ashton, A.R., Hatch, M.D. (1983) Regulation of $\mathrm{C}_{4}$ photosynthesis: regulation of pyruvate, Pi dikinase by ADP-dependent phosphorylation and dephosphorylation. Biochem. Biophys. Res. Commun. 115, 53-60

Bhalla, P., Bennett, J. (1987) Chloroplast phosphoproteins: 
phosphorylation of a $12 \mathrm{kDa}$ stromal protein by the redox controlled kinase of thylakoid membranes. Arch. Biochem. Biophys. 252, 97-104

Birkenhead, K., Walker, D., Foyer, C. (1982) The intracellular distribution of adenylate kinase in the leaves of spinach, wheat and barley. Planta 156, 171-175

Budde, R.I.H., Chollet, R. (1986) In vitro phosphorylation of maize leaf phosphoenolpyruvate carboxylase. Plant Physiol. 82, 1107-1114

Chafouleas, J.G., Balton, W.E., Hidaka, H., Boyd, A.E., Means, A.R. (1982) Calmodulin and cell cycle: Involvement in regulation of cell-cycle progression. Cell 28, 41-50

Cline, K., Werner-Washburne, M., Andrews, J., Keegstra, K. (1984) Thermolysin is a suitable protease for probing the surface of intact pea chloroplasts. Plant Physiol. 75, 675-678

Coughlan, S.J., Hind, G. (1986) Protein kinases of the thylakoid membrane. J. Biol. Chem. 261, 14062-14068

Douce, R.A., Block, M.A., Dorne, A.J., Joyard, J. (1984) The plastid envelope membranes: Their structure, composition and role in chloroplast biogenesis. Subcell. Biochem. 10, $1-84$

Edelman, A.M., Blumenthal, O.K., Krebs, E.G. (1987) Protein serine/threonine kinases. Annu. Rev. Biochem. 56, 567-613

Erdmann, H., Böcher, M., Wagner, K.G. (1982) Two protein kinases from nuclei of cultured tobacco cells with properties similar to the cyclic nucleotide-independent enzymes (N I and N II) from animal tissue. FEBS Lett. 137, 245-248

Foyer, C. (1984) Phosphorylation of a stromal enzyme protein in maize (Zea mays) mesophyll chloroplasts. Biochem. J. 222, 247-253

Gowda, S., Pillay, D.T.N. (1982) Cyclic AMP independent protein kinases from soybean cotyledons (Glycine max L.). Plant Sci. Lett. 25, 49-59

Glover, C.V.C., Shelton, E.R., Brutlag, D.L. (1983) Purification and characterization of a type II casein kinase from Drosophila melanogaster. J. Biol. Chem. 258, 3258-3256

Hathaway, G.M., Lubben, T.H., Traugh, J.A. (1980) Inhibition of caseinkinase II by heparin. J. Biol. Chem. 225, 8038-8041

Hathaway, G.M., Traugh, J.A. (1979) Cyclic nucleotide independent protein kinase from rabbit reticulocytes. J. Biol. Chem. 254, 762-768

Hathaway, G.M., Traugh, J.A. (1983) Casein kinase II. Methods Enzymol. 99, 317-331

Hidaka, H., Inagaki, M., Kawamoto, S., Sasaki, Y. (1984) Isoquinolinesulfonamides, novel and potent inhibitors of cyclic nucleotide dependent protein kinase and protein kinase C. Biochemistry 23, 5036-5041

Joyard, J., Billecocq, A., Bartlett, S.G., Block, M.A., Chua, N.H., Douce, R. (1983) Localization of polypeptides to the cytosolic side of the outer envelope membrane of spinach chloroplasts. J. Biol. Chem. 258, 10000-10006
Keegstra, K., Yousif, A.E. (1986) Isolation and characterization of chloroplast envelope membranes. Methods Enzymol. $118,316-325$

Kuo, J.F. (1974) On the question of the existence of a guanosine adenosine triphosphate specific protein kinase activated by adenosine $3^{\prime}: 5$-monophosphate dependent protein kinase. J Biol. Chem. 249, 1755-1759

Laemmli, U.K. (1970) Cleavage of structural proteins during the assembly of the head of bacteriophage $T_{4}$. Nature 227, $680-685$

Laing, W.A., Christeller, J.T. (1984) Chloroplasts phosphoproteins: distribution of phosphoproteins within spinach chloroplasts. Plant Sci. Lett. 36, 99-104

Lienhard, G.E., Secemski, J.J. (1973) $\mathrm{P}^{1}, \mathrm{P}^{5}$-Di(adenosine$\left.5^{\prime}\right)$ pentaphosphate, a potent multisubstrate inhibitor of adenylate kinase. J. Biol. Chem. 248, 1121-1123

Lin, Z.F., Luzero, H.A., Racker, E. (1982) Protein kinases from spinach chloroplasts. J. Biol. Chem. 257, 12153-12156

Murakami, S., Strotmann, H. (1978) Adenylate kinase bound to the envelope membranes of spinach chloroplasts. Arch. Biochem. Biophys. 185, 30-38

Ranjeva, R., Boudet, A.M. (1987) Phosphorylation of proteins in plants: Regulatory effects and potential involvement in stimulus/response coupling. Annu. Rev. Plant. Physiol. 38, $73-93$

Schindler, C., Hracky, R., Soll, J. (1987) Protein transport in chloroplasts: ATP is prerequisit. Z. Naturforsch. 42 c, 103108

Soll, J. (1985) Phosphoproteins and protein kinase activity in isolated envelopes of pea (Pisum sativum L.) chloroplasts. Planta 166, 394-400

Soll, J. (1988) Purification and characterization of a chloroplast outer envelope bound ATP-dependent protein kinase. Plant Physiol. 87, 898-903

Soll, J., Bennett, J. (1988) Localization of a $64 \mathrm{kDa}$ phosphoprotein in the lumen between the outer and inner envelopes of pea chloroplasts. Eur. J. Biochem. 175, 301-307

Soll, J., Buchanan, B.B. (1983) Phosphorylation of chloroplast ribulose biphosphate carboxylase/oxygenase small subunit by an envelope-bound protein kinase in situ. J. Biol. Chem. 258, 6686-6689

Ventimiglia, F.A., Wool, I.G. (1974) A kinase that transfers the $\gamma$-phosphoryl group of GTP to proteins of eukaryotic 40 S ribosomal subunits. Proc. Natl. Acad. Sci. USA 71, 350-354

Yan, T.F.J., Tao, M. (1982) Purification and characterization of a wheat germ protein kinase. J. Biol. Chem. 257, 70377043

Received 5 May; accepted 8 August 1988 